\title{
ANALISIS KANDUNGAN GULA REDUKSI PADA GULA SEMUT DARI NIRA AREN YANG DIPENGARUHI pH DAN KADAR AIR
}

\author{
Naja wilberta ${ }^{1}$ \\ Nge Titin Sonya ${ }^{2}$ \\ Solle Hartini Realista Lydia ${ }^{3}$ \\ ${ }^{1,2,3)}$ Jurusan Pendidikan Biologi, FKIP, Universitas Kristen Artha Wacana, Oesapa, Kupang \\ E-mail: ${ }_{\text {wilbertanaja@gmail.com }}$
}

\begin{abstract}
This research was conducted at the UPT Health Laboratory of East Nusa Tenggara Province, Kelapa Lima District, Kupang City from August to September. This study aimed to determine the reduction in the sugar content of ant sugar in palm sap which is influenced by $\mathrm{pH}$ and water content. The samples used were palm sap and sugar from the processing of palm sap. This research uses a descriptive quantitative analysis method. The variables measured were the reduction in sugar levels before and after the inversion as well as $\mathrm{pH}$ and water content. Analysis showed that the content of reducing sugars before inversion was $5.18 \%$ and the content of reducing sugars after inversion was $10.31 \%$. While the water content of the sap before the inversion was $76.44 \%$ and after the inversion was $2.8 \%$, the pH before the inversion was 6 and after the inversion 7. Therefore, it is advisable to continue research to see the effect of microbial and yeast populations on sugar content, reducing palm sap.
\end{abstract}

Kata Kunci: kandungan gula, gula semut, reduksi gula, pH dan kadar air

\section{PENDAHULUAN}

Indonesia merupakan wilayah yang memiliki kekayaan alam melimpah. Berbagai jenis tumbuhan di Indonesia mempunyai banyak manfaat bagi kelangsungan hidup manusia. Salah satunya adalah tanaman aren (Arenga pinnata) yang termasuk dalam kelompok palmae. Sekarang ini, tanaman aren telah banyak dibudidayakan karena pemanfaatan tanaman aren tidak hanya terletak pada buah, batang, dan daun, tetapi tanaman aren juga dapat menghasilkan nira. Cukup banyak jenis tanaman yang dapat menghasilkan nira diantaranya aren, kelapa, tebu, sagu, kurma, nipah, dan siwalan.

Nira merupakan suatu minuman alami yang terasa manis karena mengandung glukosa. Kandungan glukosa pada nira menyebabkan nira banyak diolah sebagai gula tradisional oleh kebanyakan masyarakat di beberapa daerah (Hidayati, 2009). Proses pengambilan nira bisa dilakukan dengan cara digiling, diperas, dan disadap. Nira juga dapat diolah menjadi minuman ringan seperti sirup, gula air, gula cetak dan nira juga biasa difermentasi menjadi semacam minuman beralkohol yang disebut tuak, di daerah timur (Papua) disebut sageru,dan dipulau Timor Kupang disebut Tuak laru (Pontoh, 2007).

Kualitas nira yang baik akan menghasilkan gula dengan kualitas yang baik pula. Nira yang disadap pada pagi hari memiliki $\mathrm{pH}$ dan kadar sukrosa lebih rendah dari nira yang disadap pada sore hari. Hal ini karena pada saat siang hari terjadi penguapan lebih besar dibanding pada saat malam hari (Rachman, 2009). Pada proses fermentasi nira kandungan gula akan menurun dengan cepat, sementara kandungan asam seperti asam asetat dan laktat cenderung meningkat, perubahan ini ditandai dengan penurunan $\mathrm{pH}$ dan 
kadar gula. Menurut Safari (1995), pH pada nira harus berada pada kisaran yang ditentukan agar nira dapat diolah menjadi gula, yaitu $\mathrm{pH}$ harus berkisar 67,5 .

Gula aren merupakan produk tanaman aren melalui pengolahan nira dengan cara pemasakan untuk menguapkan air sampai menjadi cairan kental yang kemudian dijadikan sebagai gula cetak atau gula semut. Namun unsur sukrosa pada nira relatif cepat terurai dengan adanya aktifitas mikroba, mengakibatkan terjadinya perubahan $\mathrm{pH}$ menjadi asam. Nira yang sudah masam tidak cocok untuk pembuatan gula granular atau gula semut karena gula tidak mengkristal.

Gula semut (brown sugar) adalah gula merah palma (palm sugar) yang dikristalkan. Beberapa alasan yang menyebapkan gula semut aren lebih sehat dibandingan dengan gula pasir adalah kalori yang terkandung didalam gula semut aren lebih kecil dibandingkan dengan gula putih sehingga gula semut aren sering disebut sebagai gula rendah kalori, dan gula semut aren juga memiliki indeks glikemik yang lebih rendah yaitu sebesar 35 sedangkan pada gula pasir indeks glikemiknya sebesar 58. Nilai indek glikemik yang lebih rendah ini membuat gula semut aren lebih aman dikonsumsi dan tidak menyebabkan lonjakan kadar gula darah yang signifikan, sehingga bisa membahayakan tubuh terutama bagi penderita diabetes. Indeks glikemik pangan merupakan indeks (tingkatan) pangan menurut efeknya terhadap kadar glukosa darah. Indeks glikemik pangan menggunakan indeks glikemik glukosa murni sebagai pembandingnya yaitu IG glukosa murni adalah 100 (Rimbawan dan Siagian, 2004). Gula semut aren juga memiliki daya tahan yang lama dan mengandung banyak kalori yang tinggi. Selain glukosa, gula semut aren mengandung serat makanan yang bermanfaat untuk kesehatan pencernaan, menurunkan kolestrol, dan membantu mengatasi maag (Mustaufik dan Dwiyanti, 2007). Dalam gula semut juga terkandung gula reduksi.

Gula reduksi adalah gula yang mempunyai kemampuan untuk mereduksi. Hal ini dikarenakan adanya gugus aldehid atau keton bebas. Senyawa-senyawa yang mengoksidasi atau bersifat reduktor adalah logamlogam oksidator seperti $\mathrm{Cu}$ (II). Contoh gula yang termasuk gula reduksi adalah glukosa, fruktosa, laktosa, maltosa, dan lain-lain. Monosakarida mempunyai kemampuan untuk mereduksi suatu senyawa. Sifat pereduksi dari suatu gula ditentukan oleh ada tidaknya gugus hidroksil bebas yang reaktif. Prinsip analisanya berdasarkan pada monosakarida yang memiliki kemampuan untuk mereduksi suatu senyawa. Adanya polimerisasi monosakarida mempengaruhi sifat mereduksinya (Rohmaningsih,2008)

Keputusan membuat gula semut dengan alasan lebih praktis, karena tidak membutuhkan alat cetakan untuk mencetak gula. Budaya masyarakat mengolah nira aren menjadi gula semut melalui pemanasan dengan suhu yang cukup tinggi yaitu $100^{\circ} \mathrm{C}-125^{\circ} \mathrm{C}$ diyakini dapat mempengaruhi komposisi gula semut nira, termasuk kandungan gula reduksi (Riko S. Jaya, Sentosa Ginting,Ridwansyah, 2016). Bertolak dari uraian tersebut maka dilakukan kajian untuk melihat apakah setelah proses pemasakan terdapat perubahan kandungan gula reduksi, kadar air dan $\mathrm{pH}$. Informasi ini dapat memberikan pemahaman kepada masyarakat tentang pengaruh pemanasan terhadap kadar gula reduksi, kadar air dan $\mathrm{pH}$ pada nira aren. Proses pemasakan pada prinsipnya memiliki sisi baik dan buruk. Memasak dapat merusak kandungan nutrisi dalam bahan pangan namun dengan proses pemasakan memberikan daya simpan yang lebih lama terhadap bahan pangan, 
membantu akumulasi nutrisi penting dan terhindar dari bakteri patogen.

Pada umumnya hasil olahan gula semut ditingkat petani dan industri rumah tangga mutunya masih rendah disebapkan pengolahan belum dilakukan secara baik, sehingga produk yang dihasilkan meleleh, karena masih mengandung kadar air yang cukup tinggi 15-17\% (Kindangen Dan Layuk 2010). Tingginya kadar air gula semut berpengaruh terhadap daya tahan simpan, umumnya produk yang disimpan bertahan kurang lebih 3 sampai 4 minggu, gula akan berubah warnah menjadi coklat kehitaman dengan struktur gula lembek dan mudah meleleh, dan dalam proses pengeringannya juga akan membutuhkan waktu yang lama pula, namun jika kadar air sesuai maka gula ini kualitasnya juga akan baik dan aromanya harum. Pada kondisi penampilan produk seperti ini nilai jual produk gula turun sebesar $50 \%$ (Lay Dan Heliyanto 2011; Soewono,2005).

\section{METODE}

Pipet $20 \mathrm{~mL}$ larutan sampel nira aren dan masukan kedalam labu ukur $250 \mathrm{~mL}$. Tambahkan $2 \mathrm{~mL} \mathrm{~Pb}$ asetat tetes demi tetes hingga endapan tidak terjadi lagi saat ditetesi dengan timbal asetat, tambahkan 6-7 tetes $\mathrm{Na}_{3} \mathrm{PO}_{4}$ 10\% agar larutan menjadi jernih, kemudian tambahkan 3-4 tetes $\mathrm{Na}_{2} \mathrm{HPO}_{4} \quad 10 \%$. Saring larutan dari beaker gelas kedalam labu ukur $100 \mathrm{~mL}$, setelah itu menghomogenkan sampel didalam beaker gelas (larutan L1) dan mengambil $25 \mathrm{~mL}$ L1 menggunakan volumerti, kemudian masukan kedalam erlenmeyer dan menambahkan pereaksi luff schoorl, untuk mempercepat proses pemanasan menggunakan hot plate selama kurang lebih 10 menit, kemudian dinginkan secara mendadak menggunakan air mengalir. tambahakan $\mathrm{H}_{2} \mathrm{SO}_{4} \quad 25 \%$ sebanyak $25 \mathrm{~mL}$ dan harus dilewatkan pada dinding erlenmeyer secara hatihati, kemudian.

Menambahkan Kl 15\% sebanyak $20 \mathrm{~mL}$ menggunakan pipet volumetri. Mentittrasi menggunakan larutan Tio sulfat sehingga saat di tetesi menggunakan indikator amilum $1 \%$ tetes indikator tidak berwarna biru tua kemudian catat volume titrasi (V1), selanjutnya membuat blanko pengujian yaitu dengan mengganti L1 dengan aquades sebanyak $25 \mathrm{~mL}$ (L2) dan mengulangi prosedur sebelumnya kemudian mencatat volume titrasi blanko pengujian V2 selanjutnya menghitung kadar gula sebelum inversi menggunakan rumus sebagai berikut :

Angka Tabel $(\mathrm{AT})=(\mathrm{V} 2-\mathrm{V} 1) \mathrm{X}$ (Normalitas $\mathrm{Na} 2 \mathrm{~S} 2 \mathrm{O} 3$ terstandarisasi / $0,1) \%$ gula sebelum inversi $=(\mathrm{AT} x$ faktor pengencer / (bobot sampel (mg) $\mathrm{x} 100 \%$

\section{Keterangan :}

$\mathrm{AT}=$ Glukosa dalam tabel

V1 = Volume titrasi sampel 1

$\mathrm{V} 2=$ Volume titrasi sampel 2

$\mathrm{Fp}=$ faktor pengencer

$\mathrm{W}=$ bobot sampel

\section{pH Gula Semut Aren}

Timbang sampel yang telah dirajang kecil kecil sebanyak 10 gram di homogenkan menggunakan mortar dengan $20 \mathrm{ml}$ aquades selama 1 menit. Tuangkan kedalam beker glass $10 \mathrm{ml}$, kemudian diukur pH-nya dengan menggunakan $\mathrm{pH}$ meter. Sebelum $\mathrm{pH}$ meter digunakan, harus ditera kepekaan jarum penunjuk dengan larutan buffer $\mathrm{pH}$ 7. Besarnya $\mathrm{pH}$ adalah pembacaan jarum penunjuk $\mathrm{pH}$ setelah jarum skala konstan kedudukannya.

Kadar Air Gula Semut Aren

Uji kadar air gula semut aren, cawan porselin dengan penutup dibersihkan dan dikeringkan dalam oven pada suhu $105^{\circ}-$ $110^{\circ} \mathrm{C}$ selama 1 jam. Kemudian didinginkan dalam desikator selama 30 menit dan ditimbang beratnya (A gram) Sampel ditimbang sebanyak 25 gram dan 
ditaruh dalam cawan porselin yang telah diketahui beratnya (B gram). Sampel dalam porselin ini kemudian dikeringkan dalam oven pada suhu $105^{\circ}-110^{\circ} \mathrm{C}$ sampel konstan selama 24 jam, selanjutnya didinginkan dalam desikator selama 30 menit dan ditimbang (C gram) - Penimbangan ini diulang sampai diperoleh berat yang konstan.

Adapun presentase kadar air yang dapat dihitung sebagai berikut:

Kadar air $=(\underline{B-C}) \times 100 \%$

$$
(\mathrm{B}-\mathrm{A})
$$

Dimana:

$\mathrm{A}=$ Berat kering cawan (gr)

$\mathrm{B}=$ Berat kering cawan dan sampel awal (gr)

$\mathrm{C}=$ Berat kering cawan dan sampel setelah dikeringkan (gr)

\section{HASIL DAN PEMBAHASAN}

Tabel 1. Data uji analisis gula reduksi menggunakan metode lufft schoor

\begin{tabular}{|c|c|c|c|c|c|c|c|}
\hline \multirow[t]{3}{*}{$\begin{array}{l}\mathrm{N} \\
\mathrm{o}\end{array}$} & \multirow[t]{3}{*}{$\begin{array}{l}\text { Nama } \\
\text { sampel }\end{array}$} & \multicolumn{4}{|c|}{ Volume $\mathrm{Na}_{2} \mathrm{~S}_{2} \mathrm{O}_{3}(\mathrm{~mL})$} & \multicolumn{2}{|c|}{$\begin{array}{l}\text { Kadar Gula } \\
\text { Reduksi }\end{array}$} \\
\hline & & I & II & $\begin{array}{c}\text { Rata } \\
- \\
\text { Rata }\end{array}$ & $\begin{array}{c}\text { Blan } \\
\text { ko }\end{array}$ & $\begin{array}{l}\text { Sebe } \\
\text { lum }\end{array}$ & $\begin{array}{l}\text { Setel } \\
\text { ah } \\
\text { Inver }\end{array}$ \\
\hline & & & & & & $\begin{array}{c}\text { Inve } \\
\text { rsi }\end{array}$ & si \\
\hline 1 & Nira & 20 & 25 & 22.5 & $\begin{array}{l}12.9 \\
5\end{array}$ & 5.18 & - \\
\hline 2 & $\begin{array}{l}\text { Gula } \\
\text { Semut }\end{array}$ & 15 & 25 & 20 & $\begin{array}{l}25.7 \\
8\end{array}$ & & 10.31 \\
\hline
\end{tabular}

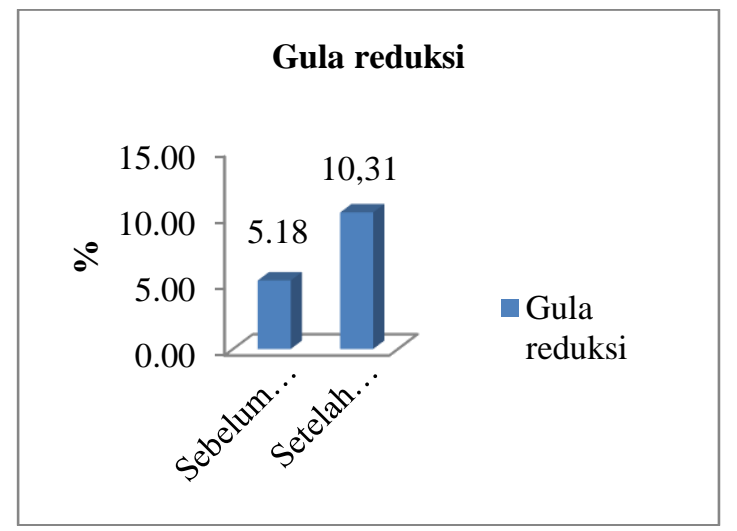

Gambar 1. Diagram analisis gula reduksi (Naja, 2020)

Berdasarkan diagram hasil uji analisis gula reduksi diperoleh rata-rata kandungan gula reduksi pada nira aren sebanyak $5,18 \%$ dan pada gula semut aren sebanyak 10,31\%. Hal ini disebapkan dari proses pemasakan sehingga terjadi peningkatan kandungan gula reduksi sebanyak $5,13 \%$ di bandingkan dengan nira aren sebelum dimasak. Gula reduksi mengalami perubahan dapat dipengaruhi oleh berbagai faktor salah satunya yakni pemanasan, dimana akibat dari proses pemanasan menyebabkan terjadinya perubahan struktur kimia maupun komposisi nira dan gula semut aren.

Hal ini dapat dilihat dari perubahan nilai gula reduksi sebelum inversi dan setelah inversi. Dari diagram diatas faktor lain yang mempengaruhi perubahan nilai gula reduksi pada nira dan gula semut aren yakni kandungan asam, dimana kandungan sukrosa bersifat non pereduksi, karena tidak mempunyai gugus $\mathrm{OH}$ yang reaktif tetapi dengan adanya asam maka sukrosa akan di hidrolisis (penguraian zat) dengan bantuan panas menjadi gula invert, yaitu glukosa dan fruktosa yang merupakan gula reduksi. Menurut Sakri (2012), pemecahan ikatan glikosidik akibat pemanasan akan membuat gulagula non reduksi (sukrosa) dapat dipecah menjadi gula reduksi seperti glukosa dan fruktosa.

Kandungan gula pereduksi juga turut berperan dalam proses pencoklatan. Warna kecoklatan pada gula semut disebabkan adanya reaksi browning Maillard dan karamelisasi yang menghasilkan pigmen melanoidin (pigmen warna coklat). Zuliana, (2016) menyatakan bahwa proses pemanasan dapat menyebapkan reaksi maillard antara gula dan asam amino yang terdapat didalam cairan nira sehingga menghasilkan warna coklat. Warna gula semut yang terlalu pucat disebapkan karena reaksi pencoklatan yang terjadi kurang sempurna. Reaksi pencoklatan yang terjadi pada pembuatan gula semut adalah reaksi karamelisasi.

Suhu pemanasan mempengaruhi reaksi karamelisasi yang terjadi selama pemasakan gula semut atau gula merah. 
Reaksi karamelisasi terjadi karena gula (glukosa, fruktosa, sukrosa, dll) dipanaskan hingga mencapai titik lelehnya, sehingga semakin tinggi suhu pemasakan semakin tinggi intensitas warna gula yang dihasilkan. Selain itu, gula invert dapat mengalami oksidasi menjadi asam-asam (asam aldonat, dan asam ketonat).

Keberadaan gula invert tersebut menandakan adanya hidrolisa sukrosa yang tidak dikehendaki dalam nira. Kerusakan nira dipengaruhi oleh berbagai faktor seperti penurunan $\mathrm{pH}$, aktifitas mikroba, kadar air dan proses hidrolisis gula reduksi dalam nira. Proses yang dikenal dengan inversi sukrosa pada dasarnya merupakan hidrolisis sukrosa menjadi glukosa dan fruktosa. Gula dengan kandungan glukosa atau gula inversi tinggi akan sulit mengeras dan daya simpan pendek karena mudah meleleh (Indahyanti, 2014).

Tabel 2. Data analisis kadar air gula semut aren

\begin{tabular}{clc}
\hline No & Nama sampel & Jumlah (\%) \\
\hline 1 & Nira & 76,44 \\
2 & Gula semut & 2,80 \\
\hline
\end{tabular}

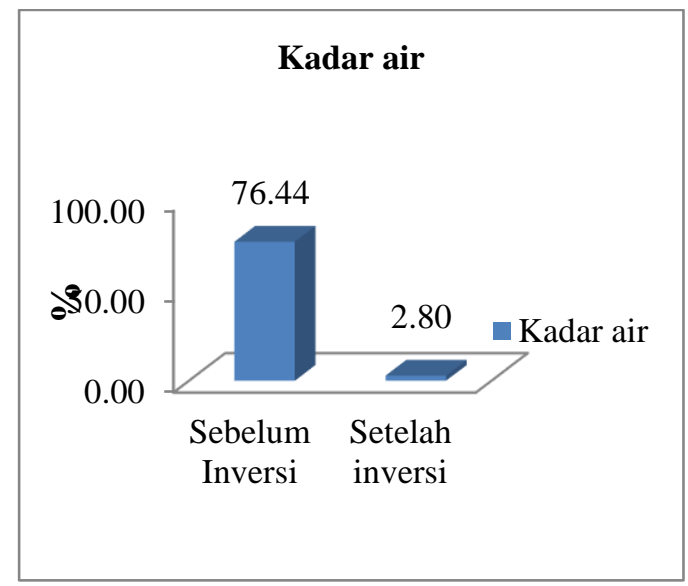

Gambar 2. Diagram analisis kadar air (Naja, 2020)

Berdasarkan diagram di atas menunjukkan bahwa nira aren memilki jumlah kadar air yang lebih banyak yaitu sebesar $76,44 \%$ dibandingkan dengan gula semut aren yang memiliki kadar air sebesar $2.80 \%$. Hal ini menunjukan bahwa setelah proses pemasakan terjadi penurunan kandungan kadar air dari $76.44 \%$ menjadi 2.80\%. Agus (2012), menyatakan adanya penguapan air selama pemanasan menyebabkan kadar air menurun dan konsentrasi padatan akan meningkat. Penurunan kadar air juga akan menambah tingginya kadar zat gizi yang tertinggal.

Perbedaan presentasi kadar air sebelum inversi dan setelah inversi di pengaruhi oleh beberapa hal yakni pemanasan, dimana lama waktu pemanasan menyebapkan terjadinya penguapan. Tekanan uap air pada bahan umumnya lebih besar dari tekanan uap air di udara, sehingga terjadi perbedaan massa air dari bahan ke udara yang di percepat dengan proses pemanasan sehingga menyebabkan terjadinya penguapan. Tingginya jumlah kadar air pada nira aren disebabkan karena nira tersebut belum dilakukan proses pemasakan ataupun pemanasan sehingga presentasi kadar airnya lebih tinggi, sedangkan gula semut memiliki kadar air yang lebih rendah karena telah melalui proses pemasakan maupun pemanasan.

Jika penguapan semakin tinggi maka kadar air semakin turun sehingga persentase total gula semakin meningkat. Berdasarkan Sutrisno (2014) adanya proses pemanasan dapat mempengaruhi kadar gula, hal tersebut dikarenakan terjadi penurunan kadar air sehingga persentase kadar gula meningkat. Proses pemasakan sangat berpengaruh terhadap kadar air dari sampel karena pemasakan tentunya menggunakan panas dan suhu yang tinggi sehingga dengan adanya panas maka kadar air bebas yang terdapat dalam bahan akan mengalami penguapan sehingga menyebabkan terjadinya penurunan jumlah kadar air 
pada bahan seperti yang terjadi pada sampel gula semut aren.

Pernyataan Fitriani (2008) bahwa semakin lama waktu pemasakan kadar air akan menurun, menyebabkan penguapan air lebih banyak sehingga kadar air dalam bahan semakin kecil. Presentasi kadar air dalam gula semut aren akan berpengaruh pada daya simpan gula semut aren tersebut dimana diagram menunjukan kadar air dalam gula semut aren berada pada angka $2.8 \%$, hal ini sesuai dengan dengan syarat mutu gula merah (SII 0268-85), yaitu kadar air maksimal 3\%.

Lebih lanjut (Kristianingrum,2009) menyatakan bahwa keunggulan dari gula semut yang memiliki kadar air maksimal 3\% dapat disimpan selama 1 tahun tanpa bahan pengawet. Kadar air yang tinggi mengindikasikan mutu gula kristal kurang baik (Rumayar et al., 2011). Menurut Heldman (2012) semakin lama proses pemasakan maka proses penguapan air bebas dalam produk akan semakin tinggi.

Tabel 3. Data analisis pH pada gula semut aren

\begin{tabular}{clc}
\hline No & Nama sampel & Jumlah (\%) \\
\hline 1 & Nira & 6 \\
2 & Gula semut & 7 \\
\hline
\end{tabular}

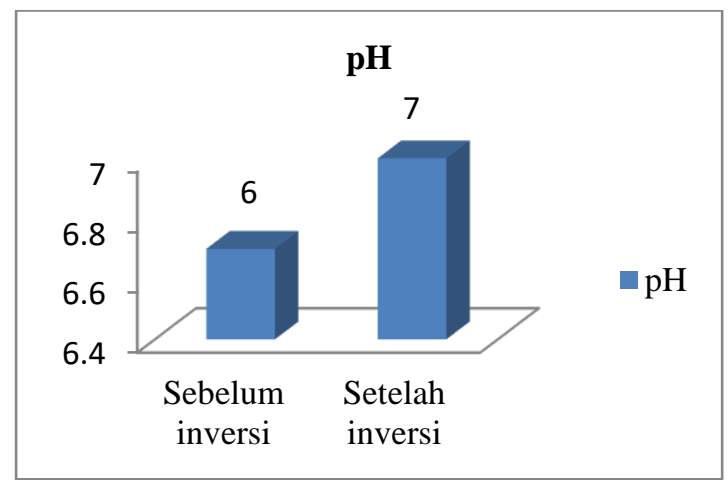

Gambar 3. diagram analisis $\mathrm{pH}$ (Naja, 2020)
Diagram diatas menunjukkan bahwa $\mathrm{pH}$ pada nira aren sebelum dilakukan proses pemasakan berada pada angka 6 dan setelah proses pemasakan menjadi gula semut aren berada pada angka 7. Data pada diagram diatas juga menunjukan bahwa $\mathrm{pH}$ gula semut aren yang berada pada angka 7 memberikan kesimpulan bahwa gula semut aren pada penelitian ini berpengaruh pada daya simpan untuk jangka waktu yang lama.

Hal ini juga dapat disebabkan oleh pengaruh suhu tinggi selama proses pemasakan sehingga dapat menghambat aktivitas enzim invertase dan mikroorganisme sehingga sukrosa tidak mengalami banyak kerusakan dan penurunan nilai $\mathrm{pH}$ akan semakin kecil. Sesuai dengan pernyataan Paustian (2007) yang menyatakan bahwa sel mikroorganisme dapat mengalami lisis pada suhu tinggi akibat meningkatnya liquiditas membran sel hingga akhirnya pecah.

Semakin tinggi suhu yang digunakan dapat membunuh mikroorganisme patogen, menghambat enzim invertase bahkan membunuh semua mikroorganisme yang ada di dalam bahan pangan. Sukrosa yang terdapat dalam nira aren tidak terfermentasi dengan baik oleh mikroorganisme awal, yang memang sudah ada di dalam nira aren segar sehingga menghambat penurunan $\mathrm{pH}$ akibat fermentasi. Apabila $\mathrm{pH}$ gula semut aren berada dibawah kisaran normal $(6-7,5)$ maka dapat berpengaruh pada kualitas dan daya simpan gula semut aren tersebut. Hal ini sejalan dengan pernyataan (Endrika Widyastuti 2016) yang menyatakan bahwa permasalahan yang muncul pada gula semut yang terdapat di pasaran adalah memiliki $\mathrm{pH}$ yang terlalu rendah.

Rendahnya nilai $\mathrm{pH}$ pada gula semut aren di pengaruhi berbagai faktor salah satunya yakni, keberadaan 
mikroorganisme yang hidup dalam bahan pembutan gula semut aren, dalam hal ini yaitu nira aren itu sendiri. Budiyanto (2004) menyatakan bahwa nira merupakan media pertumbuhan yang subur bagi mikroorganisme seperti bakteri Acetobacter aceti dan ragi dari genus Saccharomyce cerevicae.

\section{KESIMPULAN}

Berdasarkan hasil uji kandungan gula reduksi pada gula semut aren yang dipengaruhi $\mathrm{pH}$ dan kadar air dengan metode Luff Schoorl menunjukan pada nira aren sebelum dimasak dan setelah dimasak menjadi gula semut aren, mengandung gula reduksi. Namun, kadar gula reduksi pada gula semut aren lebih tinggi yaitu $10.31 \%$ dibanding kadar gula reduksi pada nira aren yaitu 5,18\%. Selain gula reduksi, terjadi perbedaan nilai kadar air dan $\mathrm{pH}$ dari nira sebelum dimasak dan setelah dimasak dan diolah menjadi gula semut. Hal inilah yang mempengaruhi pembentukan gula reduksi. Dimana kadar air yang dihasilkan dari gula semut aren adalah sebesar 2,8\% dan pH 7 sedangkan untuk nira aren sebelum dimasak mengandung kadar air sebesar 76,44\% dan pH 6.

\section{SARAN}

Perlu dilakukankan penelitian lanjutan untuk mengetahui pengaruh populasi mikroba ataupun khamir terhadap kandungan gula reduksi.

\section{DAFTAR RUJUKAN}

Agus, Martua I. 2012. Pengaruh Suhu dan Lama Waktu Ekstraksi Terhadap Sifat Kimia dan Fisik Pada Pembuatan Minuman Sari Jahe Merah dengan Kombinasi Penambahan Madu Sebagai Pemanis.Jurnal Pangan dan Agroindustri.

Budiyanto, M., 2004. Mikrobiologi Terapan. Edisi 3. UMM-Press, Malang.
Fitriani, Shanti. 2008. Pengaruh Suhu dan Lama Pengeringan Terhadap Beberapa Mutu Manisan Belimbing Wuluh (Averrhoa bilimbingL.) Kering. Jurnal Teknologi Pangan.

Heldman, Dennis. R. 2012. Food Procces Engineering Second Edition. The AVI Publishing Company, Inc. Wesport

Hidayati, N. 2009. Manfaat Pohon Aren.( http://niahidayati.net).

Indahyanti, E. B. Kamulyan. \& B. Ismuy anto. 2014. Optimasi konsentrasi garam bisulfit pada pengendalian kualitas nirakelapajurnal penelitian. Saintek. Medan. PP: 22-42

Kristianingrun 2009. Analisis Nutrium Dalam Gula Semut. Jueusan Pendidikan Kimia Fakultas Matematika Daan Ilmu Pengetahuan Alam Universitas Negeri Yogyakarta

Kindangen Dan Layuk 2010. Analisis Pendapatan Dan Sistem Pemasaran Peng-Usahaan Gula Mera Aren Didesa Wongkai Dan Pangu, Kecamatan Ratahan, Kabupaten Minahasa Tenggara, Provinsisulawesi Utara. Seminar Nasional Pengkajiandan Diseminasi Inovasi Pertanian Mendukung Program Strategis Kementrian Pertanian. Cisarua, 922 Desember 2010

Lay, A dan karouw 2005. Nira aren dan teknik pengendalian produk olahan. Buletin palma; (31) : 116125

Mustaufik dan Dwiyanti, H. 2007. Rekayasa Pembuatan Gula Kelapa Kristal yang Diperkaya dengan Vitamin A dan Uji Preferensinya kepada Konsumen. Laporan Penelitian Peneliti Muda Dikti Jakarta. Jurusan Teknologi Pertanian Unsoed Purwokerto (tidak dipublikasikan). 
Paustian, T., 2007. Microbiology and Bacteriology. Universitas Indonesia. Jakarta.

Pontoh, J. 2007. Analisa Komponen Kimia dalam Gula dan Nira Aren. Laporan pada Yayasan Masarang.Tomohon.

Rachman B, 2009. Karasteristik Petani dan Pemasaran Gula Aren di Banten. Forum Penelitian Agro Ekonomi. Volume 27 No. 1.

Riko S. Jaya, Sentosa Ginting,Ridwansyah, 2016. Pengaruh Suhu Pemanasan Dan Lama Penyimpanan Terhadap Perubahan Kualitas Nira Aren. Volt.4 No.1 TH.2016.

Rimbawan dan Siagian, A., 2004. Indeks glikemik Pangan, Cara Mudah Memilih Pangan yang Menyehatkan. Penebar Swadaya

Rohmaningsih, 2008. Pengaruh Cara Pengeringan Terhadap Kadar Gula Reduksi Pada Sale Pisang. Program Studi Pendidikan Kimia. Fakultas Sains Dan Teknologi. Universitas Islam Negeri Sunan Kalijaga.Yogyakarta. PP: 7-28.

Rumayar, H., J. Pontoh dan Kowel. 2011. Kristalisasi sukrosa pada pembuatan gula gula kristal dari nira aren. Buletin palma 12 (2) : 100-114. Pusat Penelitian Dan Pengembangan Perkebunan Bogor.

Sakri, F. M. 2012. Madu dan Khasiatnya Suplemen sehat Tanpa Efek Samping .Diandra Pustaka Indonesia.Yogyakarta. PP: 10-42.

Safari, A., 1995. Teknik Membuat Gula Aren. Karya Anda, Surabaya.

Sutrisno, C.D.N. 2014.Pengaruh Penambahan Jenis dan Konsentrasi Pasta (Santan dan Kacang) Terhadap Kualitas Produk Gula Merah.Jurnal Pangan dan Agro Industri.

Zuliana,crysse, endrika Widyastuti, dan Wahono Hadi Susanto.2016. Pembuatan Gula Semut Kelapa
(Kajian pH Gula Kelapa Dan Konsentrasi Natrium Bikarbonat). Jurnal Pangan Dan Argoindustri Vol.4 No 1 P. 109-119. FTP Universitas Brawijawa, Malang. 